
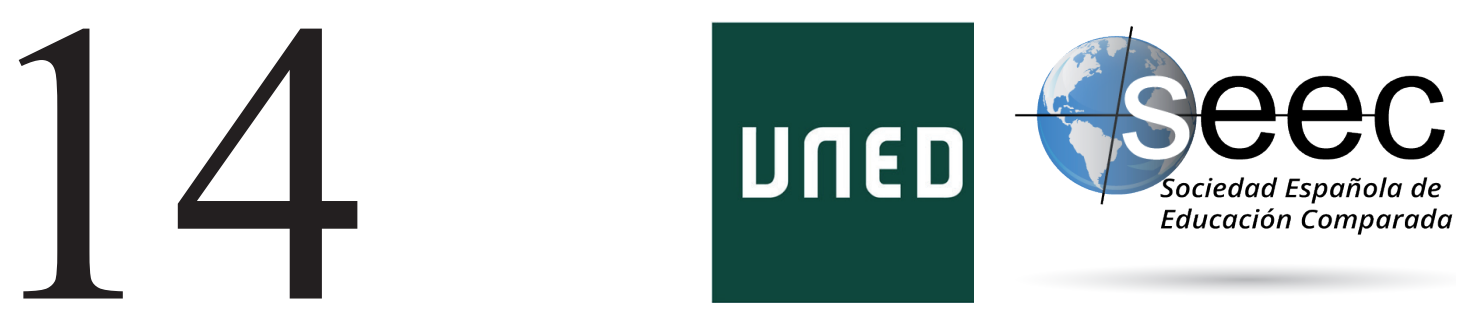

\title{
School principals' pre-service training in Spain and in the USA: alignments between higher education and supranational recommendations
}

La formación inicial de los directores de centros docentes en España y en Estados Unidos: relación entre la educación superior y las recomendaciones supranacionales

\section{Carmen Tortosa Álvarez*}

DOI: $10.5944 /$ reec.37.2021.27821

Recibido: 1 de julio de 2020 Aceptado: 19 de noviembre de 2020

\footnotetext{
*Carmen Tortosa Álvarez: Profesora de Secundaria en el Estado de Washington (USA). Doctoranda en Educación por la Universidad Autónoma de Madrid. Grupo de Investigación sobre «Políticas Educativas Supranacionales» (GIPES)/ Secondary School Teacher in Washington State (USA). PhD on Education final year student at Universidad Autónoma de Madrid (UAM). Member of Research Group "Supranational Education Policies" (GIPES). Datos de contacto: e-mail: carmen.tortosa@outlook.es
} 


\begin{abstract}
This article tackles one of the relevant issues related to the professionalization of school principals' role: their pre-service training or, in other words, the mandatory training they receive before they can take the roles as public-school principals. We conducted a research study about the recommendations by the international organizations selected. On the other hand, the study about the cases of Spain, and specifically the Region of Madrid, and the USA, and specifically the State of Washington, let us draft some conclusions about the policies and practices on this matter within these countries and regions.

After the analysis of the sources and documents, we initiated the descriptive phase of both the recommendations given by the supranational organizations and the policies and practices around this issue by the selected units. Once this phase was completed, we conducted the comparative and juxtaposition study between the chosen units and, between these and the recommendations by the international organizations. This comparative study is what lead us to draft the conclusions of this research study. As a result, the professionalization of the school leadership convenience is supported and justified. On the other hand, and in relation to the alignment among recommendations, practices, and policies around pre-service training of school principals, this study explains the most relevant parallelism and differences. This article aims to serve education stakeholders to further develop their work towards the improvement of the school principals' pre-service training and, more widely, towards the professionalization of school leadership.
\end{abstract}

Keywords: school principals; pre-service training; higher education; international organizations; standards; recommendation.

\title{
Resumen
}

Este artículo aborda uno de los asuntos relevantes en torno a la profesionalización de la dirección escolar: su formación inicial o, en otras palabras, la formación obligatoria que los futuros directores de centros escolares deben completar antes de tomar posesión de sus puestos en los centros docentes públicos. Se ha realizado un estudio sobre las recomendaciones dadas por las organizaciones supranacionales seleccionadas en torno a este asunto. Por otro lado, la investigación realizada sobre los casos de España - y concretamente sobre la Comunidad de Madrid - y sobre Estados Unidos - y concretamente sobre el Estado de Washington - nos permite trazar algunas conclusiones acerca de las políticas y prácticas en formación inicial de directores de centros educativos en los países y regiones estudiados.

Tras un análisis de las fuentes y documentos utilizados, se ha procedido a la fase descriptiva tanto de las recomendaciones aportadas por las organizaciones supranacionales, como de las políticas y prácticas educativas en torno a este asunto por parte de las unidades seleccionadas. Una vez completada la fase descriptiva, se ha realizado un ejercicio comparativo y de yuxtaposición entre las unidades escogidas y, también, de éstas con las recomendaciones de las organizaciones internacionales. Este ejercicio comparativo es el que nos ha permitido trazar las conclusiones del estudio. Se apoya y se justifica, a raíz del estudio realizado, la conveniencia de la profesionalización de la dirección escolar. Por otro lado, y en torno al asunto del alineamiento entre recomendaciones, prácticas y políticas educativas sobre la formación inicial de los directores escolares, el estudio aborda los paralelismos y diferencias más relevantes. Este artículo busca servir de utilidad a los distintos agentes educativos en su trabajo hacia la mejora de la formación inicial de los directores de centros educativos y, de una forma más amplia, hacia la profesionalización de la dirección escolar.

Palabras clave: director de centro; formación inicial; educación superior; organizaciones internacionales; estándares; recomendacione. 


\section{Introduction}

The school leadership preparation that candidates receive before they take up their roles as school principals is internationally recognized to be key for their success once performing their new roles (OEI, 2017, p. 89). Thus, international organizations tackled this specific issue as part of their drafted reports and recommendations on school leadership. On the other hand, member states implemented measures towards the development of this training programs for future principals in the past decades.

In this article, we will mention and explain the recommendations on this issue provided by international organizations in the past ten years (2009-2019). The organizations we selected are the European Union, OECD, OEI, and UNESCO. We chose these organizations due to their active role on publishing reports and recommendations on school leadership. We wanted to select all of them instead of just those representing our two selected countries (please note that one of the countries selected, the USA, is not member of the European Union and neither of the OEI).

We will also describe and analyze the currently in place pre-service school principals' training policies and practices in two countries: Spain and the USA. For this purpose, and due to the autonomy of regions in Spain and states in the USA on education matters, we will go through the policies and practices applied to the Autonomous Region of Madrid and the State of Washington (WA State). By combining both national and regional policy measures on this issue, we will be able to provide an approximation to the current reality of pre-service principals' preparation programs in these two countries. We will analyze the pre-service training required in both countries to future school principals willing to lead public schools providing basic education.

After studying the countries and the international organizations selected, we will analyze the alignments on this matter between the pre-service training systems in the units selected and the recommendations provided by the supranational organizations. It is important to understand that we are not seeking to look for the influence by the international organizations' recommendations on the pre-service training of future school principals, but rather the existence or inexistence of an alignment between the two.

The comparative methodology was at the core of this article. We selected and analyzed the supranational organizations publications, the current legislation in both units selected, and the pre-service training programs information. The descriptive phase of the article is followed by a comparative and juxtaposition phase, in which we looked for alignments and differences between the units selected and between them with the recommendations provided by the international organizations.

This research methodology serves the purpose of this article, which is to describe the current state of pre-service school principals' training together with the supranational recommendations and the alignment between them. This way, we will be contributing to future analysis and actions by policy makers or programs providers. Our final goal is to support the work and efforts towards the development of the professionalization of school leadership as a valuable source of schools' improvement. 


\section{Recommendations by the international or- ganizations on school principals' pre-service programs}

In the past ten years, international organizations such as the European Union, OECD, OEI and UNESCO have tackled and supported the need for a greater professionalization of school leadership. An appropriate training of school principals is one of the first steps for this purpose and thus, the international organizations have also made recommendations on this specific matter, with the aim to influence policy makers in their member states. In this section, we will go through a relevant selection of those supranational suggestions on pre-service school principals' preparation.

The European Union (EU) supports and enhances the achievement of a good quality school leadership ${ }^{1}$. In 2008, the European Commission launched a platform for the improvement of the school leadership, stating - under its recommendation number eight - the need for the development of a pre-service and professional development adequate for school principals. In May 2009, the Council of the EU approved the ET 2020, where the following statement was included: it is important to improve the education and training centers' governance and leadership and to launch effective systems to guarantee quality' (p. 4).

Some months later, in November 2009, the Council approved its Conclusions on the professional development of school teachers and principals (2009/C 302/04). On this document, the EU stated that the preparation programs for teachers and principals should be adapted to their needs, should combine academic research and practice, and should be coherent with the pre-service preparation programs (2009/C 302/04, p. 7). The Council stressed that setting the principals' profile, their recruitment process and their pre-service preparation was key for their future performance as principals (2009/C 302/04, p. 8). Through these conclusions, the EU also recommended its Member States to encourage teachers and principals to participate on the EU transnational mobility programs (2009/C 302/04, p. 9).

In 2010 the EU recommendations on principals pre-service preparation were further specified when the European Commission celebrated a working group where its members reached an agreement on issues such as the principals responsibilities, the skills and competences they would need to perform well at their jobs, and the general parameters for the principals' pre-service preparation programs (European Commission, 2010, p. 6).

The European Commission added that principals needed legal skills about the schools' legal framework, and other skills to develop an strategic leadership, for the creation of a good learning environment, for achieving team engagement, and making analysis and improvement of teaching and learning (European Commission, 2010, p. 6). It also stated that these skills should be acquired by preparation programs that should set specific and clear learning goals, based on active learning, with different learning methodologies, and focused to tackle the preparation needs of each participant (European Commission, 2010, p. 6).

$1 \quad$ This article does not aim to conduct a historic study but a static one, for which, and due to space limitations, we briefly explain a selection of the supranational organizations' recommendations on this topic within the last twelve years. 
In 2011 the European Union created the European Policy Network on School Leadership with the aim of giving recommendations to the Member States on measures to improve school leadership. In this network participated, among other stakeholders, academic and research institutions. One of the three main work areas of this platform was focused on building skills and capacity on school management towards the adequate teaching and learning achievements.

Years later, Vassiliou ${ }^{2}$, in a conference in 2013 on School leadership, stated that Member States should improve the principals' preparation programs, among other issues (Vassiliou, 2013, p. 4). She mentioned some of the Council of the European Conclusions on this matter: the need to define the skills that the principals should have, and to design - according to those skills - education possibilities that include the use of technology and administration techniques (Council of the European Union, 2013, p. 3). This document also recommended Member States to benefit from the Erasmus+ Program and the eTwinning Platform ${ }^{3}$.

In 2014, the Council of the European Union approved its Conclusions about school leadership where they reiterated on the previous recommendations on several issues such as the skills needed, the recruitment process, assessment of administrators, and pre-service and in-service preparation (Council of the European Union, 2014, p. 3).

Thus, from 2009 to 2014 the European Union gave recommendations to the Member States on principals' pre-service preparation. Up until 2010, they focused on stressing the idea for the need of an appropriate principals' pre-service preparation. From to 2010 to 2013 the European Union insisted on this need and added specific suggestion on the content for this pre-service preparation. They were all broad recommendations, but they set a path to be followed by Member States on this matter.

After 2014, there was a decrease on the attention given by the European institutions to this subject. The European Policy Network on School Leadership stopped operating on the same year - 2014. Even though the Council of the European Union approved Conclusions in 2017 where they mentioned the need for including practical experience abroad for novice and future school leaders (Conclusions on school development and excellent teaching, 2017/C 421/o3), the main issue of these more recent EU recommendations were not the professionalization of school principals, but a broader sense of school leadership and other education aspects. We can see that once the EU gave its recommendations on this matter, its education priorities transitioned to other important and newer fields.

We will analyze in the conclusions of this article the extent of alignment between those recommendations given by the European Union from 2009 to, mainly, 2014 on principals' pre-service training with the decision-making process of one of the countries analyzed within the lines below: Spain. Before that, we will mention and analyze the work done on this subject by another institution that studied this issue and gave recommendations to its country members: the OECD - international organization where both the USA and Spain belong.

2 European Commission Director General of Education, Culture, Multilingualism, and Youth at the time 3 Erasmus+ is a European Union initiative that promotes the mobility of students and education staff and the exchange of good practices and innovation among educative institutions staff. School leaders could benefit from these opportunities. For more information, please check: https://ec.europa.eu/programmes/ erasmus-plus/resources_en, eTwinning Platform is a Europea Union network or online community for school staff to share good practices and resources. For more information, please check: https://www. etwinning.net/en/pub/index.htm 
In 2009, the OECD published two important documents on school leadership: Improving School Leadership: working tools and The Leadership Toolkit. Through these documents, the OECD recognized the importance of this field and mentioned obstacles for an effective leadership such as a greater complexity of the principals' jobs and an imbalance between the complexity of the job and its conditions (Pont et al., 2009a, p. 9).

Based on the idea of the need for those practices - taken from 19 OECD countries and 22 educative systems -, the OECD came up with recommendations such as to develop principals' skills for an effective school leadership (OCDE, 2011). The OECD emphasized the importance of principals' pre-service and in-service training and, thus, the relevance of the institutions in charge of providing these programs achieving coherence between content and goals. Other recommendations by the OECD on this matter are to prioritize practice instead of theory, to apply the content to the needs and context of the schools where the principals will most likely work (Pont et al., 2009a, pp. 21 - 22).

In a document published in 2012, Schleicher ${ }^{4}$ wrote about the importance of the relation between the strategic management of resources with the academic goals, which required principals' to receive a better preparation (Schleicher, 2012, p. 20). This idea of the need for a good principals' pre-service preparation was also included in the Talis 2013 report (OCDE, 2014b, pp. 79-81) and it was further developed in another paper published by Schleicher in 2015, where the author stated the need for the development of formal pre-service programs (Schleicher, 2015, pp. 34 - 35).

In 2019, the OECD published new data on schools' principals' pre-service preparation under TALIS 2018. Even though they focused on publishing the results of the survey where they ask principals of its country states about their formal training before taking up the role as principals, the OECD also quotes statements stressing the proven good effects of principals preparation programs on principals' engagement in instructional leadership practices such as teacher collaboration, higher qualifications of teams of teachers, and school improvement progress (OECD, 2019, p. 136). This quote is not a direct recommendation, however, together with the survey conducted on pre-service training for principals, they confirm the importance given by the OECD to this matter.

Thus in the past decade, the OECD stressed the importance and suggested it members to better develop the professionalization of school principals by redesigning aspects such as the selection process, tasks, and also their skills before taking their jobs, by providing them with good opportunities to participate in formal pre-service preparation programs, well adapted to their goals and schools context.

In the past years, UNESCO also tackled the school leadership issue, and more specifically, the principals' pre-service training, by including it in their conversation and goals on education.

In 2005, they launched the Education for All - the Qualitive Imperative report where UNESCO suggested to provide the schools with more freedom and autonomy and to get the principals' competences and responsibilities clearly defined so they could truly impact their schools quality and efficiency (Maureira, 2006, p. 1). Years after, under the 2030 Agenda for Sustainable Development framework and, more specifically, its Sustainable Development Goal 4, which aims to 'ensure inclusive and equitable quality education and promote lifelong learning opportunities for all', they tackled in some of its targets the need to improve school leadership. 
The background paper on School Leadership, trends in policies and practices, and improvement in the quality of education, under the Education for All Global Monitoring Report 2015 - Education for All 2000 - 2015: achievements and challenges recognizes the need for the school principals training to be reconsidered together with their responsibilities and the expectations towards them (Vaillant, 2015, p. 1). The document states that "retraining and training of school principals and leaders is very important since they are the people who apply education policies in schools, so if they are poorly trained and supported, no policy, be it national or regional or local, can be effective“" (Vaillant, 2015, p. 4).

The paper also provides some recommendations on this matter after analyzing four case studies. The first suggestion is to consider the creation of an institute run for and by teachers and principals, which combines research with teaching and school leadership practice. This institute could be attached to the country's government through the Ministry of Education and it can include the specialization and accreditation of school leaders and principals based on national professional standards (Vaillant, 2015, p. 5).

The paper also suggests the training for an effective leadership of principals and the increase of quality of education (Vaillant, D., 2015: 9). It emphasizes this recommendation by stating that "School leadership is built on and refers to the ability to guide, inspire and motivate pupils and teachers. This ability is not innate, but can be promoted and developed through training, collaboration and exchange between peers", and adds that there are several solutions or strategies for developing school leadership (Vaillant, 2015, p. 10).

Together with these recommendations, the paper reminds the importance of the post-2015 agenda to develop sustainable leadership in the future, for which principals "must receive adequate remuneration and support" (Vaillant, 2015, p. 10).

After this, in 2016, The Incheon Declaration and Framework for Action for the implementation of Sustainable Development Goal 4 (SDG 4), covered some "indicative strategies" within each of the targets set under SDG 4. Indicative strategy number seventy-four includes the need to "strengthen school leadership to improve teaching and learning”. This strategy also includes the need to "Review, analyze and improve the quality of teacher training (pre-service and in-service) and provide all teachers with quality pre-service education and continuous professional development and support", however, it doesn't include the need to improve the quality of training for school principals or school leaders specifically (UNESCO, 2016a, p. 55).

In addition, indicative strategy n. 103 claims the need for the national governments to assess the education policy measures implemented by applying key principles for the evaluation approach, such as the school leadership among others (UNESCO, 2016a, p. 66).

Also under the 2030 agenda framework, UNESCO published a report where it compiled regional reviews of policies and practices and gave final recommendations where it insists on the need for stablishing an appropriate principals' training policy option "for successful education reform and development"(UNESCO, 2016b, p. 210). It specifies more on this matter when it adds that the training that principals receive should serve the purpose of letting the principals serve as facilitators, guide and supporter of quality instructional practices and that this can be achieved by "(re)designing their training programs (pre-service, induction and in-service) in coherence with the national competency framework for school leaders" (UNESCO, 2016b, p. 212).

This report also insists on the need for policy makers to consider approving a competency framework to serve as a guide for principals training and professional development, 
among others (UNESCO, 2016b, p. 211). The report adds that UNESCO contributes to this end by "promoting technical cooperation and partnership among countries and relevant institutions (donors, universities, professional networks, etc.) for the development of effective school leadership" (UNESCO, 2016b, p. 215).

Later, through documents such as its Policy Brief on School Leadership in Central Asia, UNESCO insisted on the need for principals to receive a proper school leadership pre-service and in-service training and also added that this training "needs to be specifically developed for the needs of schools leaders with a focus on education management" (UNESCO, 2019, p. 3). For this purpose, it establishes the need to link school leader training on effective school leadership to official certifications, career and teacher competency frameworks, to allow for career progression (UNESCO, 2019, p. 4).

Thus, it is correct to say that UNESCO also made recommendations on this matter to its member states. All of these recommendations are aligned with the idea that there is a need to improve school leadership and that, to reach the attraction and retention of school principals, together with improving quality of instructional practices, the school principals need to receive an adequate and formal pre-service preparation training, focused on school management, and leading to an official certification.

The Organization of Ibero-American States for Education, Science, and Culture (OEI) published in 2017 a report where this organization stated that the school principals need, in addition to their knowledge and experience on teaching, a differentiated and specific education on school administration, being the pre-service preparation the first step in this process (OEI, 2017, p. 87). The report adds that the pre-service education needs to focus on "key competences (knowing, knowing to do, knowing to be) that are all interrelated to each other" (OEI, 2017, p. 89). According to the OEI, this need for a pre-service preparation on school administration is recognized internationally and this is the reason why the future principals are usually required to complete pre-service education on matters such as school management, school leadership, and human resources management, among others, (OEI, 2017, p. 89).

Under this context, the OEI recommends that, aiming to get a real professionalization of the school administration, the Ibero-American States should develop a recruitment and pre-service preparation upon agreement within the education stakeholders and respecting a necessary school autonomy (OEI, 2017, p. 168). It adds that the mentioned pre-service preparation should be stable experiences - meaning that it should go beyond courses -, contextualized, and it should be focused on the reality of each school, always aiming to develop a professional career of the person that participates on this preparation (OEI, 2017, p. 168).

Thus, the OEI recommended the Ibero-American countries in 2017 to develop a formal and locally oriented pre-service preparation program for school principals to get them ready for the new profession they would be willing to enter.

Two years later, in 2019, the OEI launched a report on School leadership where it analyzed, among other issues, the required or optional opportunities of pre-service provided to the candidates to become school principals. This time - and following the conclusions by Pont et al. (2009b) - the OEI insists and elaborates on its recommendation about the convenience for their member states to develop good quality pre-service programs and to contextualize it according to the reality of the school where the new administrators will serve by guaranteeing a coherent syllabus, internships in schools where the future school principals can get mentoring and coaching (OEI, 2019, p. 28). 
The OEI supports the argumentation of these recommendations by referencing various relevant sources on the subject matter.

The 2019 OEI report lists the eight dimensions or responsibilities that Day et al. in 2010 (as cited in Bolivar et al., 2013, p. 29) believe a school principal should have:

1. To define the vision, values and mission, building trust

2. To improve the teaching and learning conditions

3. To restructure the organization: to redesign roles and responsibilities

4. To improve teaching and learning

5. To redesign and to enrich the curriculum

6. To improve the teachers' quality

7. To build relationships within the school community

8. To build relationships outside the school community

In addition to these eight dimensions, the OEI also mentions some of the conclusions published by UNESCO on its report on recommendations to Latin America on education policies, written by Treviño et al. (2016); and that we mentioned some pages above when we described the UNESCO recommendations on school leadership pre-service preparation.

The OEI adds on its 2019 report some conclusions on the matter by other international organizations such as the European Union (EU), and the OECD; and by well-known authors in this subject matter such as Inmaculada Egido and Day et al. The report states that the OECD and the EU as the International Organizations that published the most about school leadership in the last years before 2019 (OEI, 2019, p. 36).

The OEI also points out a theory already published by Inmaculada Egido: the countries reforms did not always follow the recommendations by the international organizations, but it worked the opposite way - the international organizations learnt from the countries case studies and drafted some of their recommendations following successful patterns (OEI, 2019, p. 41).

In the two reports we mentioned on this pages, the OEI quotes the report published by Cuenca and Pont (2016) when it says that it is key to set policies on the pre-service preparation programs for school principals as the quality of their leadership will be impacted by this preparation. Cuenca and Pont (2016, p. 39-40) asked the following questions: where should the future school administrations' pre-service preparation should take place? Should it be a specialization of the teaching preparation? Should it be a different career? Should it be a graduate specialization?

The OEI, as we can see, not only is aligned to the recommendations by the two most influential international organizations and authors on this subject matter, but also quotes them as their sources of reference to support the recommendations they provide to its member states.

After analyzing the recommendations given by these four international organizations - the European Union, OECD, UNESCO, and OEI -, we can conclude that they are all aligned on the idea that school quality is closely related to schools' principals' impact and, therefore their skills and, more specifically, to their pre-service preparation training. In addition to their insistence on this general statement, each of them gave further and more specific recommendations that we mentioned above and will summarize below.

The European Union, for instance, mentions the need for the school principals' pre-service preparation programs to include the use of technology and administration techniques (Council of the European Union, 2013, p. 3), a combination of research and 
practice, the development of legal skills applied to schools, and of skills for the creation of a good learning environment, for the improvement of teaching and learning quality, and for the improvement of team engagement - all of this within programs designed to be effective and contextualized for each of their participants (European Commission, 2010, p. 6).

The OECD mentions the relevance of the institutions in charge of providing these programs so they can design them and implement them in a coherent way between content and goals, which should imply, according to the OECD, now just to combine theory and practice, but to prioritize practice in a real context over theory (Pont et al., 2009a, p. 21-22).

UNESCO links the need for an improvement on school principals' pre-service and in-service preparation with the important role principals have on developing national and regional educative policies within the schools (Vaillant, 2015, p. 4). UNESCO adds the possibility for member states to create training institutes attached to the Education Ministries to provide and oversee this kind of training for its educations (Vaillant, D., 2015: 5) and they also suggest the need to link this training with official certifications (UNESCO, 2019, p. 4).

The OEI insists on the need for a locally contextualized pre-service training for principals (OEI, 2017, p. 168), on the need for including an internship in the programs (OEI, 2019, p.28), and it recommends its member states to get this training to be focused on key competences (OEI, 2017, p. 89).

The four of them differ on some of the areas of focus for their recommendations on this subject but they all recognize the importance of school principals pre-service preparation training and, furthermore, they understand this issue as part of the needed professionalization of school principals' role and the needed redesign of their responsibilities due to the constant changes of school needs and circumstances. They also connect the need for formal pre-service training with the international challenge of improving the attraction and retention of school principals, which is proven to be related to the lack of skills and support they all need for a good performance of their tasks.

\section{School principals' pre-service preparation programs in Spain and the U.S.A.}

According to TALIS 2018, schools' principals in Spain have an average of 23,7 years of teaching experience compared to the OECD principals' average: 19,9 years (OECD, 2019, p. 51). In the same report, principals were asked about the six most important areas of need for more professional development. In Spain, principals stated that they needed to get further training in the following areas: leadership for enhancing team work, human resources management, data use to improve the school quality, design of teachers professional development initiatives, school financial management, and knowledge and understanding of the current education policies (OECD, 2019, p. 55).

In Spain, $26 \%$ of principals said that they had never received any instructional leadership training compared to $17 \%$ in the OECD and $4 \%$ in the USA (OECD, 2019, p. 40). The average age of principals in Spain is 50 years old, whereas in the USA it is 48 years old and in the OECD is 52 years old (OECD, 2019, p. 85); being 9\% of the principals in Spain, 17\% of the US principals, and 20\% of OECD principals, 60 years old and above (OECD, 2019, p. 48). 
In the USA, the percentage of lower secondary principals who received formal training on school administration before taking up the role as a principal was over $80 \%$, and 90\% received instructional leadership programme or course (OECD, 2019, p. 136). In Spain, however, over 50\% of principals stated that they received school administration training program or course before starting their jobs as principals and about $45 \%$ said they received an instructional leadership training program (OECD, 2019, p. 136). The USA scores third when comparing these results to the rest of the OECD countries - after Singapore and Finland -, and Spain scores below the OECD average. It is important to keep in mind that this data was collected in 2018 - year in which, as we will see below, pre-service training was not mandatory yet for principals in Spain.

Differences between the two countries can be also found when comparing the participation in professional development courses or seminars by principals from Spain and from the USA: in the twelve months prior to the TALIS 2018 survey, almost 50\% of the principals in Spain attended courses or seminars about leadership compared to the 80\% of the principals in the USA (OECD, 2019, p. 167). In this case, Spain scores again below the OECD members average and USA scores higher than the OECD members average.

These differences are linked to the policies on this matter in each of these countries and in its regions or states. In this section, we will describe the policies and practices on school principals' pre-service training in each of our selected cases. The Spanish region selected is the Autonomous Region of Madrid and the American state selected in the State of Washington.

\subsection{Spain and the Autonomous Region of Madrid: a mandatory program for future principals}

Spain covers a territory of 504.645 sq. Km., from which the Autonomous Region of Madrid covers 8.022 sq. Km, according to the Spanish government data. In January 2019, over 47 million people lived in Spain and, of those, 6.642 million lived in the Autonomous Region of Madrid.

In 2018/2019, Spain had a total of 28.449 schools, of which 19.090 were public schools. Over 650.000 educators worked in almost 19.000 schools that offered Elementary, Middle School, High School and Vocational Training education; of which more than 14.000 worked in public schools - according to the Spanish Ministry of Education. There are over 1.400 Elementary, Middle, and High Schools in the Autonomous Region of Madrid, of which over 1.100 are public schools. In 2018/2019, there were six public universities and seven private universities in the Autonomous Region of Madrid.

The Education System in Spain currently follows the national regulation approved in 2006: the Organic Law of Education (LOE - according to its Spanish acronyms), which was partially modified in 2013 with the approval of the Law for the Improvement of Education (LOMCE according to its Spanish acronyms). It is the responsibility of each autonomous region in Spain, such as the Autonomous Region of Madrid, to develop the national regulation by approving additional norms that comply under the national ones.

In Spain, the pre-service preparation of principals willing to serve at public schools is currently set by the education law in force - LOMCE -, that modifies the previous law of education - LOE -. This preparation requirement does not apply to candidates willing to serve at private schools.

One of the modifications set by LOMCE was about the school principals pre-service preparation program. Article 134 part 1 of the LOE was modified and included a new 
requirement for future principals to be recruited: to have an evidence of certification of having passed a training program on school administration. The general characteristics and goals for content and skills of this course were designed by the Spanish Ministry of Education with the aim of providing future principals with the practical, general, and specific skills they will need for the success on their performance (RD 894/2014, preamble). The implementation of this new pre-service preparation is the responsibility of the Spanish Regional Departments of Education. In other words, the Spanish Ministry of Education sets the goals and general instructions for the program and the Regional Departments of Education are responsible for the implementation and further development of those instructions and for providing the candidates with opportunities to attend those courses in each of the Autonomous Regions of Spain.

This new pre-service program for principals was thought to have a combination of practical and theoretical content (RD 894/2014, art. 2 part 2) and must have a duration of at least one hundred and twenty hours - excluding extra content added by the Autonomous Regions' Departments of Education (RD 894/2014, art. 2 part 5). They are all valid in the country and not just in the specific regions, and they can be taught by the education supervisors of each region, by other school principals, by university professors and researchers, by the Education Ministry and Autonomous Regions' Departments of Education staff, and by other experts (RD 894/2014, art. 3 part 3). In addition to this, it is also relevant that these courses can be provided by institutions that may receive the permission by the Autonomous Regions' Departments of Education to do so (RD $894 / 2014$, art. 3 part 3).

The new education law also stated that this course would not be compulsory until 2019 but that it would be valued as a merit for the hiring process of school principals in all the Spanish regions between 2014 and 2018. In January 2019 the new pre-service preparation for school principals became compulsory.

The goals for skills and content to be acquired and developed by the participants of these courses were set by the Spanish Government under the LOMCE. The goals for skills were divided into generic competences and specific competences.

The generic competences are the following (RD 894/2014, Annex 1, part 1):

a) "Teamwork leadership skills

b) Engagement skills

c) Information management and decision-making skills

d) Communications skills

e) Conflict and coexistence management skills

f) School organization, management, and coordination skills

g) Skills for strategic school leadership: planification, implementation, plans and projects assessments.

h) Control and supervision skills

i) Change management and innovation skills"

The specific competences are the following (RD 894/2014, Annex 1, part 2):

a) "Set of norms relevant to schools

b) Use of Information and Communication technologies

c) Administrative and economic management

d) Human resources management

e) Institutional documentation management 
f) Time and spaces management

g) Participation of the educative community and image promotion

h) Institutional management

i) Assessment, improvement plans, and achievement of school quality“

The minimum content required for the pre-service preparation training under the LOMCE is divided into six compulsory modules (RD 894/2014, Annex 2):

1) "Regulatory framework applied to schools

2) Organization and management of schools

3) School resources management

4) Key factors for an effective school leadership

5) Assessment and education quality

6) School leadership plan“

Each of these modules are divided into several compulsory sections - from five to nine depending on the module. These modules and sections are compulsory for all the school principals' pre-service preparation programs in Spain. In other words, each program offered in any region in Spain needs to comply with, at least, this content and skills.

In the case of the Autonomous Region of Madrid, for instance, this program is offered by the Department of Education through its centers for educators' professional development in the different parts of the region and by CRIF Las Acacias 5 . If we take one of these training programs offered in the professional development center for educators in the region of Madrid - CRIF Las Acacias -, we would see that the program follows the content and skills goals set by the national law and that it develops the national law by stablishing course items such as the teachers in charge of providing the contents, the schedule and place of the course, the combination of a face to face and an online modality, and the assessment approach.

In addition to the Autonomous Regional Departments of Education, universities are also allowed to offer these preparation programs to future school principals and, as soon as they follow the compulsory skills and content set by the national and the adequate regional regulatory framework on this matter, the title provided will be taken into consideration at the principals recruitment process of public schools in any region in Spain. In the Autonomous Region of Madrid, for instance, there are several public and private universities that provide a principals' pre-service preparation program - usually postgraduates.

In the Autonomous Region of Madrid, public universities such as Rey Juan Carlos University, Complutense University of Madrid, and Autonomous University of Madrid; and private ones such as Antonio de Nebrija University, Camilo Jose Cela University, Comillas Pontifical University, Distance University of Madrid, European University of Madrid, and Francisco de Vitoria University they all offer or have offered in the past years either masters or courses on school leadership that comply with the skills, content and the minimum hours required by national and regional regulations. These higher education institutions started offering their current school leadership programs at different moments from 2009 until 2019. But it is relevant to say that most of the postgraduate

$5 \quad$ Due to limited space, we can't explain all the training programs offered by the Department of Education of the Autonomous Region of Madrid, so we selected CRIF Las Acacias as one example due to the fact that this is the only one within the Department of Education training centers offering this program, which is offered to educators within all areas in the Autonomous Region of Madrid. 
programs on school management analyzed were approved after 2014 - therefore after the current education law, with the modifications on the principals' pre-service preparation policy mentioned, was approved in December 2013.

The areas covered in most of the postgraduates programs on school leadership offered in Madrid are the following: management and leadership of schools, instructional leadership, schools' assessments and education quality, innovative education, applied regulation relevant to schools, education systems compared, and the use of information and communication within the school and towards its community. They all also have a requirement for the participants to complete a final masters' dissertation - which may be or not the school leadership plan required by the national law. Three of the programs analyzed also cover content on schools marketing, and one of them focusses the school leadership program on digital transformation.

The programs analyzed cover the minimum required skills and content set by the national norms, and all of them overpass the minimum of 120 hours required by the national regulation. Instead, the postgraduate option offers a program of 60 ECTS (1.500 hours approx.). The postgraduate programs also include the requirement for their participants to have an internship experience aiming at applying the theoretical knowledge acquired and the new skills set developed. The minimum hours required by each institution to pass the internship requirement varies from 4 to 12 ECTS credits, being 6 ECTS credits the most common choice by the school leadership postgraduate programs offered in the Autonomous Region of Madrid.

It is important to notice that, even though the preamble of the national regulation mentions the relevance of the combination of theory and practice in these preparation programs, the practical part of the program - understood as a real experience in a real setting - is not mentioned as mandatory in the regulation. Maybe the preamble, when referring to practice, aimed to address the requirement for participants to design a school leadership plan - which is included in the regulation. This difference between possible interpretations of the word 'practice' within this context is important for this analysis.

Overall, in the situation we described in this section, we saw that higher education institutions take the applicable regulation and comply with it. We described how all the higher education institutions we analyzed but one got their approvals to be able to start offering their principals pre-service postgraduate programs after the national law was approved.

Thus, we could link the design and approval of these programs with the requirements previously set by policy makers. But we can also provide an interpretation that goes beyond this first one: higher education institutions in the Autonomous Region of Madrid didn't just comply with the state and regional norms, but improved it by transforming a 120 hours course in 1500 hours postgraduate programs, which let participants get deeper into their knowledge acquisition and development of their school leadership skills. These programs also improved the requirements made by the national law by including an average of 6 ECTS credits or 150 hours internship in a real setting or, in other words, in a real school. This is probably done this way by the universities so they can adjust the course to a higher education official title and, this way, also compete with the 120 hours courses provided by the Autonomous Regions' Departments of Education.

It is also interesting to notice that the principals' pre-service program that was approved before the LOMCE was passed, as it is the case for the two higher institutions that offer not a program but a subject on school management, have clear similarities with 
the norm's requirements in both the content and the skills covered. They all comply with the minimum hours' requirement too.

A possible interpretation for this coincidence on the characteristics between the postgraduate program and the national norm is that, even though the program was approved before the law, the university may have adopted the new requirements and, this way, may have modified its program so it complies with the new law.

\subsection{The USA and the State of Washington: standards to follow and intern- ships to complete}

The USA has a population of around 330 million people, in a territory of almost 10 million sq. Km. There are fifty states, one of which is Washington State (WA), located in the Pacific Northwest area. WA State covers more than 184.000 sq. Km, and has a population of almost 7.615 million people, according to the US census data of July 2019.

According to the National Center for Education Statistics, in 2016/2017 there were a total of over 97.00o public elementary, middle and high schools in the USA. Over a million students attend every year public schools in WA State and more than 63.000 teachers worked in 294 different school districts of the state. In 2011/2012 there were almost 1,800 principals employed in the State of Washington (Campbell et al., 2014, p. 3).

Each state in the USA has its own educational system which gets implemented with the help of school districts that, complying with the state regulations, have certain extent of autonomy to implement those regulations. There is also federal educative regulation, being the current one the Every Student Succeeds Act (ESSA), approved in December 2015, and there are also national institutions that provide recommendations to the states in different education matters. But ultimately, the states are the ones in charge of designing and implementing their own education system. In the USA, basic education covers the attendance of students to school since they are six years of age until they are sixteen or eighteen, which depends on the state where the student lives.

In the USA, school principals have the opportunity or the requirement to participate and pass a specific program on school leadership if they want to become school principals. The current national education law -ESSA- covers this aspect of the preparation of future school administrators when it states that the "Educational Leaders Residency Programs' should be a year long program, with practical learning and where participants will be assessed within a real school context (ESSA, 2015, Sec 2002, Title II).

Under this general national framework, there are more specific recommendations by the National Policy Board for Educational Administration (NPBEA) on this matter: The National Educational Leadership Preparation (NELP) standards, which are the national standards on skills and content for the pre-service preparation programs of future principals. They were published in 2018, aligned to the Professional Standards for Educational Leadership (PSEL) and substituting the previous ELCC standards for novice principals, in force since 2011 (NELP Standards, 2018, p. 2). The new standards were thought to set expectations on the quality of achievement of some skills considered necessary for the school principals' performance. The issues covered by the NELP standards are the following (NELP Standards, 2018):

- Standard 1: Mission, vision, and improvement

- Standard 2: Ethics and Professional Norms

- Standard 3: Equity, Inclusiveness, and Cultural Responsiveness 
- Standard 4: Learning and Instruction

- Standard 5: Community and External Leadership

- Standard 6: Operations and Management

- Standard 7: Building Professional Capacity

- Standard 8: Internship

Thus, according to these eight standards, it is important to note that the preparation programs for future school principals tackle the development of skills on setting the vision for a school, ruled by ethics, professional norms, and cultural responsiveness. To follow the national standards, these programs also need to provide future principals with knowledge and tools to be instructional leaders that can build professional capacity among their staff and that master the community and external relations. The participants of the programs will also need to develop operations and management skills. For all this, they will need to acquire theoretical knowledge, but they will also need to have the opportunity to put that knowledge in place through an internship experience in a real setting.

The National Educational Leadership Preparation (NELP) standards are not mandatory for the States to follow. One of the states that do follow the NELP standards is the State of Washington. In WA State, these standards serve as a guide for universities to plan their principals' pre-service preparation programs and for the State of Washington Professional Educator Standard Board (PESB) to approve the programs proposals delivered by the universities, and once approved, assess their quality with periodical assessments (PESB Strategic Plan 2016 - 2020, 2016, p. 4).

In addition to the national standards, the programs providers in the State of Washington also need to comply with certain WA State standards that complement the national standards. This state standards are set by PESB and are designed to assess not the quality indicators of the curriculum of the principals' pre-service preparation programs, but the minimum expectations about the general characteristics of all educators' programs.

According to PESB (PESB, Program Standards, 2018, p. 1-10) and the State regulation (WAC 181-78A-220), universities that offer educators programs in WA State - and therefore those that offer principals pre-service preparation programs - need to "recruit, select, support, and prepare diverse cohorts of candidates with potential to be outstanding educators" (Domain 1). They should also "prepare candidates who demonstrate the knowledge, skills and cultural responsiveness required for the particular certificate and areas of endorsement, which reflect the state's approved standards" (Domain 2) and should prepare "candidates who are role ready" (Domain 3). The providers should "contribute positively to state and local educator workforce needs" (Domain 4). They should also "maintain data and assessment systems that are sufficient to evaluate program performance, direct program decision-making, inform state-level priorities, and report to the board" (Domain 5). They should also provide field-based and practice experience (Domain 6) and should "ensure that programs have adequate resources, facilities, and governance structures to enable effective administration and fiscal sustainability" (Domain 7).

In addition to these state standards for educators' preparation programs, PESB also designed a set of indicators to periodically evaluate principals' pre-service preparation programs. Thus, these items are also taken into consideration by universities when they design and develop their principals' pre-service programs. Those indicators that the PESB use since 2018 are the following: participants' GPA when they enter the program, percentage of past participants working in WA State after one year from graduation, 
those who worked in WA State a year after graduation and still worked two years after that moment, difference between women and men that completed the program between 2015 and 2018, difference between white and black participants that completed the program between 2015 and 2018, women participating in this program vs. women enrolled at the same university, and the number of participants of color participating in these programs vs. people of color enrolled in the same university (PESB, 2018).

All these NELP standards and PESB standards and indicators are taken into consideration by the universities when they design their program proposals and, later, develop and implement the programs. There are currently (May 2020) twenty-one principals' preparation programs in seventeen universities in WA State. All these programs have common aspects in their curriculum, which complies with the NELP standards, and they also have some peculiarities that differentiate them. This way, the universities also adapt the programs to the needs of their potential participants.

These preparation programs for the certification of future school principals are not usually masters, however, universities often offer the participants the option to upgrade the title and get the master's degree. They are usually designed to be finished in two years and they require the completion of, at least, five hundred and forty-hours internship.

The universities that offer these programs in WA State are the following: Central Washington University, City University of Seattle, Columbia Basin College, Eastern Washington University, Gonzaga University, Heritage University, Northwest University, Pacific Lutheran University, St. Martin's University, Seattle Pacific University, Seattle University, University of Washington-Seattle, Bothell and Tacoma, Washington State University-Spokane, Wenatchee, Tri-Cities and Vancouver, Western Governors University - Washington, Western Washington University, and Whitworth University.

For the purpose of drafting some conclusions about the characteristics of these programs, we conducted a brief study and we analyzed the programs offered by five of those universities. All the studied programs offered include subjects about school management and leadership, instructional leadership, current regulatory framework, finance, human resources and education policy. Most of them - but one - also include the school community as one of the subjects covered. There are also some subjects such as technology, school assessment, and research that are covered in these programs by some of the universities analyzed. Another difference that is important to mention is the minimum required hours for the internship. Some of the universities set this target as the NELP standards do (540 hours) and some others require their participants to do a minimum of even 1000 hours internship.

We see that there is a direct connection between the standards and the programs analyzed. The higher education institutions take these standards into account when they design and implement their programs, also when they prepare their assessment and progress reports. This compliance is also key for the higher education institutions to guarantee their participants that, once passed these programs, they will get the WA State Administrator Certificates if they fulfill the other requirements - which they must do in order to be accepted to participate in the programs.

In the case of WA State we can state that the higher education institutions take the minimum requirements and improve them by offering their participants more complete solutions such as longer internship - notice the difference mentioned above between the 540 hours internship standard and the 1000 hours internship required by one of the programs to its participants. Also, in WA State, the universities that provide the twenty-one 
principals pre-service preparation programs created WCEAP - the Washington Council of Education Administration Programs - an association where its members meet periodically and discuss challenges and further developments and improvement for their programs. This association also provide policy makers with recommendations for new quality indicators ${ }^{6}$.

Thus, this case provides us with an example of how higher education institutions can comply with the requirements set by policy makers but also improve its measures in two different ways: setting solutions for their students that provide them with a more complete preparation before taking their future roles as principals and by giving recommendations to the policy makers on what is possible and convenient to further improve or set as quality requirements for all the new and existent programs.

\section{Conclusions: school principals' pre-service training in Spain and the USA and their align- ments with supranational recommendations}

Policy makers in the Autonomous Region of Madrid and WA State recognize the importance of a good pre-service preparation training for principals and that is what they show in the regulation approved in the past decade or decades on this matter. In both, new principals must pass a training on school management where they will acquire specific knowledge and develop skills that are necessary for a successful performance of their roles. On the other hand, the same goes with the international organizations analyzed in this article: they all acknowledge the importance of an appropriate school principals' pre-service preparation training and give recommendations towards the achievement of good quality preparation.

It is important to remember that, from the study cases selected, only Spain is member of the four international organizations chosen, whereas the USA is member of two of them - OECD and UNESCO. Thus, we could expect that policy and practice in Spain may be aligned to the recommendations by the four international organizations and USA potentially to the recommendations by just the OECD and UNESCO.

The contextualization of the programs to the local realities and needs recommended by the OEI can be achieved by both Spain and the USA thank to the autonomy given to the programs' providers on the curriculum details. Another recommendation given by the OEI, which is the use of key competences in the training programs, can also be matched by Spain and the USA due to their policies requirement on focusing on content and specific school leadership skills. Even though this is not a recommendation only given by the OEI, but rather quite spread within the international education sector since the beginning of this century, it is relevant to note the existence of a parallelism on this matter too.

On the other hand, Spain and UNESCO are aligned on the idea of convenience of training institutes for educators, attached to National or Autonomous Regions' Departments of Education and not necessarily attached to universities. The beginning of this alignment may be found in the Science of Education Institutes (ICE according to its Spanish acronym), created in Spain in 1970 in coordination with UNESCO's suggestions

6 https://www.pesb.wa.gov/workforce/developing-current-educators/certification-standardsrenewal/principal-administrator/ 
at the time. As we mentioned above, the Autonomous Region of Madrid, for instance, has its own training centers for the educators employed in the public sector to get their professional development trainings, and, in addition, for principals to get their formal pre-service training too. The same does not apply in the area of the USA analyzed in this study, where higher education institutions are the only ones providing the principals' formal pre-service preparation programs.

There is another recommendation given by UNESCO that, in this case, Spain does not follow, and the USA does. UNESCO links the need for specialization and accreditation of school principals with the compliance of 'national professional standards' (Vaillant, 2015, p. 5). In this article, we described how in both, Spain and the USA, there are characteristics set by the national regulation which guide the design and implementation of the principals' pre-service programs. Those characteristics are, however, fundamentally different in both countries: in the USA they are professional standards, whereas in Spain they are specifically pre-service programs descriptors. Where the former is a guide for the American States to design all the elements affecting the career of a school principal (recruitment, selection process, pre-service and in-service training, tasks and goals to achieve in their roles, and principals' evaluation) and therefore its efficiency on impacting positively the quality of his or her school; the latter just applies to the pre-service program described in this article, but are not necessarily linked to the rest of the principals career elements, which could potentially minimize the positive effects of a coherent policy around school administration. This difference on the existence of standards for school principals to follow may find its explanation on the fact that school administration is professionalized in the USA, whether in Spain it is not.

On the other hand, in Spain, there is an alignment between the pre-service preparation national policy and the EU and OEI recommendations on the content of this training but not on one aspect: a real combination of theory and practice. This is also linked with one of the main OECD recommendations on this matter: prioritization of practice above theory.

We acknowledge the good intentions by the policy makers in Spain to include practice in the pre-service preparation programs, however the practice included in the mandatory course does not go beyond the draft of a School Leadership Plan. This differs clearly with the case of the USA, where the national standards include the recommendation to states to add an internship in their programs, so those states that follow the national standards take this as a requirement. That is the case of the State of Washington, where the pre-service preparation programs include a minimum of 540 hours internship requirement to their participants, prioritizing, in some cases, practice over theory. The USA national standards and those states that chose to follow them are aligned to the OECD, the OEI, and the EU recommendations in this matter - even without being members of the last two organizations.

Thus, principals' candidates in the USA face a future professional path in which all the elements of their new careers as school administrators are coherent among each other, starting with their pre-service program and going across all the career steps mentioned above. Also, they will have the opportunity during their training to experience the reality of the job before they take the responsibility to lead their respective buildings (schools), in which they will face different responsibilities and challenges as compared to their previous leading roles as departments leaders. These two facts give us one reason to support the idea of the convenience of a future professionalization of school leadership in Spain and, therefore, the improvements that would come with it for the principals' professional careers and the quality of education. 
It is also relevant to remember that even though internships are not part of the Spanish national policy on this issue, higher education institutions that provide postgraduate programs for future school principals in Spain do include an internship under their graduation requirements. Will this, together with the OECD, OEI, and UE recommendations, set a precedent for future policy decisions on this field in Spain? Can the programs designed by universities in Spain influence the policy makers decisions? As we described in our USA case study, that is a reality in WA State, where the Washington Council of Education Administrators Programs make recommendations to the State policy makers. Whether or not this could be happening or will happen in Spain may be the subject of future research studies.

In relation to this idea of different possibilities of influence trends among education stakeholders, this article gives us the chance to further reflect upon the nature of supranational recommendations to its member states and draft a new set of conclusions. As Egido stated (2015, p. 79), it is not just international organizations influencing its member states, but the international organizations also learning from its members and giving recommendations based on already stablished policies by those member states. In relation to this idea, we observed and mentioned in this article how the international organizations make recommendations based on their own studies, surveys and reports, but also based on others' academic research studies, on other international organizations' statements, and from their member states policies and practices. On the other hand, policy makers and academic researchers also learn from supranational recommendations and reports.

This implies that the influence trend among those education stakeholders working on the principals' pre-service preparation field may be circular and not linear; where all the stakeholders influence each other and where a group of higher education institutions make recommendations to their policy makers, where practice precedes and impact policies, in some cases.

The alignments or parallelism between the supranational recommendations and the principals' pre-service preparation programs are clear in our two case studies ${ }^{7}$. Some of these recommendations are given by the international organizations and some other ideas come from practices carried by those organizations' member states. Other recommendations given from international organizations, on the other hand, are present in the principals' pre-service programs even when they are not followed and required by their national laws.

It is this combination of influences and share of knowledge and experiences what allowed countries and regions to keep improving their principals pre-service training programs in the past decade. It is also this what will let us keep improving in the direction of achieving a better principals' pre-service preparation, a further school principals' professionalization and, therefore, a better education quality in the schools where those principals lead.

$7 \quad$ It is important to mention again - we already made this clarification in the introduction of this article - that by alignment we mean the existence of a parallelism, but not necessarily a specific and direct influence from international organizations to their member states - as the latter is not proven in this article. 


\section{References}

Bolívar, A., López Yáñez, J., and Murillo, J. (2013). Liderazgo en las Instituciones educativas. Una revisión de líneas de investigación. Revista Fuentes, 14, 15 - 60.

Bolívar A. and Bolívar R. (2013). Construir la capacidad de mejora escolar: liderazgo distribuido en una comunidad profesional de aprendizaje. Educarnos, 10(11), 1134 .

Council of the European Union, 12 May 2009, Council Conclusions for the European Cooperation on Education and Training (ET 202O) (2009/C 119/O2).

Council of the European Union, November 2009, Council Conclusions on the professional development of teachers and school leaders (2009/C 302/04).

Council of the European Union, 25 - 26 November 2013, Council conclusions on effective leadership in education. Education, youth, culture and sport council meeting Brussels.

Council of the European Union, 1 February 2014, Council Conclusions on effective leadership in education (1) (2014/C 30/02).

Council of the European Union, 8 December 2017, Council Conclusions on school development and excellent teaching (2017/C 421/03).

Council of the European Union, 19 January 2018, Discussion paper from General Secretariat of the Council to Permanent Representatives Committee/Council on Taking forward de education aspects of the European Council Conclusions of 14 December 2017 at a Policy Debate (5073/18 EDUC 2).

Cuenca R. and Pont B. (2016). Liderazgo escolar. Inversión clave para la mejora educativa. Fundación Santillana.

Day, C., et al. (2010). Ten Strong Claims for Successful School Leadership in English Schools. Londres, National College for Leadership of Schools and Childrens Services (NCSL).

Egido, I.(2015). El liderazgo escolar comoámbito de la política educativa supranacional. Bordón 67(1), $71-84$.

European Commission. (2008). Recomendaciones - Dirección escolar: Tendencias Generales y Medidas Necesarias.

European Commission, 17 - 21 October 2010, Education and Training 2020 programme Thematic Working Group 'Teacher Professional Development', Report of a Peer Learning Activity in Limassol. School Leadership for learning. Cyprus.

Ley Orgánica 2 de 2006. De educación. BOE núm. 106. BOE-A-2006-7899. 4 de mayo de 2006.

Ley orgánica 8 de 2013. Para la mejora de la calidad educativa. BOE núm. 295. BOE-A-2013-12886. 9 de diciembre. 
Maureira, O. (2006). Dirección y eficacia escolar, una relación fundamental; REICE - Revista Electrónica Iberoamericana sobre Calidad, Eficacia y Cambio en Educación, 4(4e).

Ministry of Education of the U.S. Government. (2015). Every Student Succeeds Act (ESSA).

NPBEA. (2018). National Educational Leadership Preparation (NELP) Program Standards - Building Level.

OCDE (2011). Improving School Leadership Policy and Practice. Paris: OECD Publishing.

OECD (2014a). PISA 2012 Results in Focus: What 15-year-olds know and what they can do with what they know. Paris: OECD Publishing.

OECD (2014b). Talis 2013 Results: An International Perspective on Teaching and Learning. Paris: OECD Publishing.

OECD (2019). Talis 2018 Results: Teachers and school leaders as lifelong learners. Volume 1, Paris: OECD Publishing.

OEI (2017). Miradas sobre la Educación en Iberoamérica: Desarrollo profesional y liderazgo de directores escolares en Iberoamérica.

OEI (2019). Liderazgo Directivo: Dimensiones para el análisis de la normativa sobre los directores y directoras escolares.

PESB (2016). Strategic Plan: 2016 - 2020.

Pont, B., Nusche, and D., Hopkins, D. (2009). Improving School Leadership. Volume 2: Case studies on system leadership, OECD Publishing.

Pont, B., Nusche, D., and Moorman, H. (2009). Mejorar el liderazgo escolar. Volumen 1: política y práctica, OCDE Publishing.

Real Decreto 894 de 2014. Por el que se desarrollan las características del curso de formación sobre el desarrollo de la función directiva establecido en el artículo 134.1.c) de la Ley Orgánica 2/2006, de 3 de mayo, de Educación, así como de los correspondientes cursos de actualización de competencias directivas. BOE núm. 270. BOE-A-2014-11494. 17 de octubre de 2014.

Schleicher, A. (2012). Ed., Preparing Teachers and Developing School Leaders for the 21st Century: Lessons from around the World. OECD Publishing.

Schleicher, A. (2015). Schools for 21st-Century Learners: Strong Leaders, Confident Teachers, Innovative Approaches, International Summit on the teaching profession, OECD publishing.

UNESCO (2016). Education 2030: Incheon Declaration and Framework for Action for the implementation of Sustainable Development Goal 4, Ensure inclusive and equitable quality education and promote lifelong learning opportunities for all. 
UNESCO (2016). Leading better learning: School leadership and quality in the Education 2030 agenda. Regional reviews on policies and practices.

UNESCO (2019). Policy Brief on School Leadership in Central Asia.

Vaillant, D. (2015). Education for All Global Monitoring Report 2015: School leadership, trends in policies and practices, and improvement in the quality of education. Final report. UNESCO.

Washington State regulation on Program approval standards for approved preparation programs (WAC 181-78A-220). 